\title{
RACJONALNIE O ŚMIERCI. ZMAGANIA JULII HARTWIG Z TAJEMNICĄ PRZEMIJANIA
}

Artykut zostat poświęcony wybranym utworom Julii Hartwig, w których poetka próbuje ująć w słowo - i bez watpienia jest to próba udana - jedno z najbardziej nieuniknionych $i$ tajemniczych prawidet ludzkiej egzystencji, a mianowicie konieczność umierania. Doświadczenie przemijania, a nawet stałej obecności śmierci wyraża poetka poprzez uważne przyglądanie się rzeczywistości widzialnej, oczywistej, a nawet banalnej, która jednak każdorazowo przekracza, by uchwycić to, co tajemnicze i niewyrażalne. $W$ poezji Julii Hartwig nie brakuje wizyt zmartych $w$ świecie żywych, zarówno na jawie, jak $i$ we śnie, co jest dowodem na to, że owe dwa światy - żywch $i$ umarlych przenikaja się, a może nawet więcej, że świat umartych $i$ żywch stanowia nierozerwalna jedność. Ten splot nie jest dla poetki niczym nadzwyczajnym, dlatego owe przejawy śmierci $w \dot{z} y c i u$, czy téz świata zmarlych $w$ świecie żywych opisuje w sposób zupetnie racjonalny.

Stowa kluczowe: Julia Hartwig, śmierć, przemijanie, racjonalizm.

Wprowadzenie. Julii Hartwig to poetka, którą nierzadko określa się mianem racjonalnej, a w jej poezji dostrzega się klasyczną dyscyplinę, umiar i ład. Nie ma jednak w poezji Hartwig klasycyzmu w sensie klasycystycznej jasności, ale wręcz przeciwnie - wiele w niej ciemności. Nie ma też klasycystycznego patosu i dostojności, ale głos ściszony, zainteresowanie konkretem, antynomiczne widzenie rzeczywistości i - nie od razu może widoczne, ale niewątpliwie obecne - poczucie humoru. Przede wszystkim zaś poszukiwanie harmonii - dźwięków, języka i wreszcie świata.

W harmonijnym spleceniu ukazuje poetka także życie i śmierć. Ich wzajemne przenikanie się przybiera w twórczości Hartwig postać stałej obecności zmarłych wśród żywych i stałej obecności śmierci w życiu.

Poetyckie zmagania $z$ tajemnicą śmierci. W tomikach poetyckich Julii Hartwig, zwłaszcza tych późnych (od tomiku Zobaczone, 1999 do Jasne niejasne, 2009), nie brakuje utworów poświęconych najbardziej bolesnym i niewyrażalnym koniecznościom ludzkiego istnienia - przemijaniu, odchodzeniu bliskich i bólu wywołanym rozstaniem. Jednak niepokojące przeczucie ciemnej strony egzystencji, której elementem jest stała obecność śmierci, występuje także w utworach wcześniejszych, czego przykładem jest wiersz Taras nad morzem [7]:

Łagodny szum morza towarzyszy rozmowom i śmiechom na tarasie gdzie siedzą w trzcinowych fotelach pod oknem hotelowej restauracji

Między stolikami biegają dzieci zachwycone że pozwolono im towarzyszyć rodzicom nocą

Dorodny mężczyzna mówiący po niemiecku otwiera butelkę szampana $\mathrm{z}$ takim hukiem

jakby rozpoczynał drugą wojnę światową 
i piana przelewa się przez brzegi kieliszków spiesząc na spotkanie z pianą

Egejskiego Morza

Kiedyś jego swawolący synek wspomni ten wieczór

będąc mężczyzną i zdumieje się jak młody był jeszcze wówczas ojciec

i jak pociągającą kobietą o mocnym a zarazem łagodnym zarysie brody

była matka

która nade wszystko lubiła rozmawiać o uczuciach z głową wspartą na dłoni i wzrokiem utkwionym w rozmówcy

$\mathrm{Na}$ taras wjeżdża teraz wózek inwalidzki w którym siedzi brodaty chłopak

jego przyjaciel popycha wózek jakby tańczył

Anglik

Ciemność nieba wznosi się coraz wyżej i mieni się od gwiazd

$\mathrm{z}$ których astrolog potrafiłby przepowiedzieć co zdarzy się nazajutrz

Ale jesteśmy tutaj żeby zapomnieć o wszystkim poza tym morzem

To co nas otacza wydaje się kojąco piękne i trwałe

i tarasem w nocy

piękni są również ci młodziutcy kelnerzy

którzy zginając wdzięcznie torsy podają panom koniak metaxa paniom

herbatę

i lody trzem łakomym pensjonarkom które zajęły stolik

w najciemniejszym miejscu tarasu

tuż za reflektorem w którego świetle giną migocąc skrzydłami srebrne chmury ciem

Taras nad morzem jest poetyckim impresjonistycznym obrazem przedstawiającym pogodną i beztroską wakacyjną scenę. Oto na hotelowym tarasie, przy akompaniamencie łagodnego szumu morza i w atmosferze wieczoru $\mathrm{z}$ wolna przemieniającego się $\mathrm{w}$ noc, na trzcinowych fotelach beztrosko wypoczywają goście. Słychać rozmowy i śmiechy, a także radosne okrzyki dzieci biegających między stolikami. Kelnerzy roznoszą napoje - panom koniak metaxa, paniom herbatę, słychać huk otwieranego szampana. Odmalowana przez poetkę scena emanuje spokojem, który - w wyniku zastosowania długiej epickiej frazy, wzmagającej wrażenie monotonnej melodyjności naśladującej rytm fal - udziela się również czytelnikowi. Zdaje się, że zaobserwowana chwila, której odpowiednikiem jest czas teraźniejszy (,goście siedzą”, „dzieci biegają”, „mężczyzna otwiera butelkę szampana”, „piana przelewa się"), trwa wiecznie. To moment warty wspominania: „Kiedyś jego swawolący synek wspomni ten wieczór".

Zatrzymując się na powierzchni wiersza, tzn. idąc tropem znaczeń jasnych, widzimy oczami obserwatora pogodne wakacyjne zdarzenie. Na tym jednak zadanie interpretatora się nie kończy. Uważny czytelnik dostrzeże prawie niezauważalne, bo poetka nie usuwa sprzed oczu odbiorcy urokliwej impresjonistycznej sceny, sygnały wprowadzające ton całkowicie odmienny od pogodnej i beztroskiej chwili. Jak się okazuje, jej trwałość i piękno są pozorne: „To co nas otacza wydaje się kojąco piękne i trwałe”. Co więcej, wczasowicze 
przyjechali, by „zapomnieć o wszystkim poza tym morzem i tarasem w nocy”, jakby podczas wakacji miał się zatrzymać czas.

Obok tych bezpośrednich wypowiedzi obserwatora, który nieoczekiwanie staje się uczestnikiem zdarzeń, znajdziemy inne sygnały zmiany tonu: pierwszym z nich jest pojawienie się brodatego chłopaka - Anglika na wózku inwalidzkim. Jego kalectwo zdaje się nie pasować do beztroskiej sceny, przypomina o ułomności i niedoskonałości nieusuwalnie wpisanej w ludzką egzystencję, a także o bezradności człowieka wobec wyroków losu.

Dodatkowo, w końcowych partiach wiersza poetka zwraca uwagę czytelnika na „najciemniejsze miejsce tarasu”, opanowane przez srebrne chmury ciem ginących w świetle reflektora. Wiadomo, że miejsca najciemniejsze są niebezpieczne, a nawet przeklęte, że są przestrzenią działania zła. Z kolei ćma to archetypiczny znak śmierci, symbolizuje chwilowość i momentalność. Czyżby zatem nawet w tak pięknym miejscu jak nadmorski hotelowy taras i w tak beztroskiej wakacyjnej przygodzie śmierć przypominała człowiekowi o swoim wszechwładnym panowaniu? Na to pytanie także musi odpowiedzieć czytelnik.

Taras nad morzem jest wierszem, który doskonale obrazuje sposób dochodzenia przez poetkę do niewidzialnych rejonów świata i okrytych mrokiem tajemnicy prawd. Punktem wyjścia zawsze jest rzeczywistość widzialna, którą jednak poetka każdorazowo przekracza: „Rzeczywistość widzialna stanowiła dla mnie zawsze stały punkt odniesienia. Przy całej jego ułomności, nie ma wszak świata doskonalszego niż ten, który istnieje. Ale nie ogranicza się on przecież do swojej formy. Prawda o nim, jego dostępny nam obraz, przenosi nas zarazem w jakiś przedziwny sposób w rejon niewidzialnego. Poprzez kontakt $\mathrm{z}$ nim dokonuje się przemiana rzeczywistości zewnętrznej w wewnętrzną. Doświadczenie rzeczywistości staje się $\mathrm{w}$ ten sposób rodzajem doświadczenia transcendentnego. [...] Wierzę, że można tak opisać rzecz, widok, sytuację, by czytelnik zrozumiał, że mają one jeszcze inne, ukryte sensy" [8, s. 6] (podkreślenie moje - MZB).

Konieczność umierania jest nieusuwalnie wpisana w ludzką egzystencję, to wyrok, którego w żaden sposób nie można uchylić, a jednocześnie tajemnica najbardziej chyba niewypowiadalna ze wszystkich. „Co kryje się w milczeniu, / które jest ostatnią wiedzą o tym, że koniec jest bliski?" - pyta poetka w wierszu Pieczęć (Nie ma odpowiedzi, 2001). „Wszystko, co powiedziano o tej chwili, milczenie odrzuca. / Nikt nie ma wstępu do tego milczenia". Chwila umierania jest doświadczeniem, z którym nie mogą się zmierzyć żadne ludzkie słowa, ponieważ wszystkie one są albo niewystarczające, albo zbyt płytkie ${ }^{1}$. Próbą złamania pieczęci tego wszechogarniającego milczenia jest wiersza Przemówi (Jasne niejasne, 2009):

Nim się odezwą archanielskie trąby

rozniesie się w dolinie jej żałosny głos

${ }^{1}$ Podobnie jest z samotnością: ,Krzyczy o niej każda fala choć napływa w tłumie innych fal / krzyczy o niej każdy napotkany ptak / choć odlatuje w licznej gromadzie / krzyczy o niej wiatr choć ociera się o trawy i drzewa / milczy o niej tylko człowiek patrzący w morze / milczy o niej tylko kamień”. (Krzyk samotności) [9]. 
ten od stuleci znajomy instrument

nieprzydatny w żadnym chórze czy orkiestrze

Stojąc samotnie na polanie świata

podniesie w górę swój ciężki krowi łeb

i z głębi jej udręczonego gardła dobędzie się skarga

na śmierć zwierzęcą i człowieczą

ze wspólnego artykułu zasądzoną

Tematem wiersza jest śmierć krowy ${ }^{2}$. Zwierzę stoi na polanie i wydaje się świadome zbliżania się tego granicznego momentu, czego wyrazem jest jego „żałosny głos”, ryk będący skargą na śmierć. Wizyjny charakter utworu skłania jednak czytelnika, by $\mathrm{w}$ tak opisanym zdarzeniu poszukał innych, ukrytych sensów.

Już początkowe partie wiersza budzą w czytelniku zdumienie, gdyż moment śmierci krowy zostaje ukazany jak śmierć człowieka - „odzywają się archanielskie trąby", witające w naszych wyobrażeniach duszę u niebieskich bram, zaś odchodzeniu towarzyszy bolesna jego świadomość, połączona ze skargą na ten nieunikniony wyrok. Nasuwa się zatem pytanie, dlaczego poetka - można by rzec - „uczłowieczyła” śmierć zwierzęcia, czy też dlaczego umieranie człowieka ukazała pod postacią śmierci zwierzęcia. Być może dlatego, że to właśnie za pomocą metafory krowiej śmierci stało się możliwe zwerbalizowanie tego niewyrażalnego doświadczenia.

Jednak nie są to jedyne ukryte znaczenia zawarte w wierszu. Jeśli uznać, że „archanielskie trąby” odzywają się na tak na śmierć człowieka, jak i na śmierć krowy, to można stwierdzić, że w omawianym wierszu krowa staje się symbolem każdego istnienia w ogóle - ludzi, jak i zwierząt. Zwłaszcza że krowa stoi nie na jakiejś zwykłej dosłownej polanie, ale na ,polanie świata”. Taki kierunek interpretacji wzmacnia informacja, że ,z głębi jej udręczonego gardła / dobędzie się skarga / na śmierć zwierzęcą i człowieczą / ze wspólnego artykułu zasądzoną". Jak się zatem okazuje, w obliczu śmierci wszystkie istnienia - ludzie i zwierzęce, a być może i roślinne - zostają zrównane.

Jedynie przeczuwana w Tarasie nad morzem stała obecność śmierci, w tomiku Zobaczone (1999) staje się bezpośrednią przyczyną powstania części zawartych w nich wierszy, które - mimo braku formalnych wyróżników - można czytać jako cykl trenów napisanych po śmierci męża poetki - Artura Międzyrzeckiego ${ }^{3}$. Pomijam jednak wątek autobiograficzny, poszukując rozważań o charakterze ogólnoludzkim i uniwersalnym, zgodnie z następującą opinią poetki: „Ważną sprawą dla poezji jest wybór między tym, co ogólne i co szczególne. I ile odsłonić

${ }^{2}$ Krowa jest zwierzęciem, które pojawiło się w niejednym utworze Julii Hartwig. O krowie-przyjaciółce pisze poetka we wczesnych utworach Portret I, Portret II i Portret III [3].

${ }^{3}$ Chodzi o dziewięć wierszy od Stań do Acquafondata, w których Małgorzata Czermińska odnajduje szczegóły korespondujące $\mathrm{z}$ biografią Artura Międzyrzeckiego. Zdaniem badaczki, Julia Hartwig odsłania autobiograficzny, osobisty podtekst swej poezji, ale nie składa tego wyznania wprost, lecz sprowadza pierwiastek osobisty do bycia medium (,okiem” i „wrażliwością”), przez które widać nie poetkę, ale świat i ludzi, z którymi ona się zetknęła. Zob. [2, s. 204-205]. 
się da $\mathrm{w}$ poezji, i zasłonić zarazem, $\mathrm{z}$ naszych dramatów osobistych, tak, by zapisując naszą osobowość zarazem łączyć się z innymi w tym, co najbardziej człowiecze" [5, s. 37].

Mając na uwadze tę metapoetycką wskazówkę, przyjrzyjmy się wierszowi Stań (Zobaczone, 1999):

\section{Znikasz i jesteś i znów i znów}

między światłem i cieniem między przerwami drzew

Stań zatrzymaj się połóż mi rękę na sercu

ty jesteś doskonałym instrumentem miłości

nie ma we mnie zgody na twoją zdolność odchodzenia

$\mathrm{W}$ cieniu nie jesteś sobą chcę cię znów w jasności

bólu mój moja radości tak uchwytna nawet w pamiętaniu

Jak w poemacie Śniło mi się zmarły pojawia się we śnie albo też w pamięci. Tego nie wiemy. W każdym razie poetka widzi go i z nim rozmawia, choć ta rozmowa przybiera formę monologu, zmarły bowiem ani razu nie odpowiada ${ }^{4}$. Dotkliwe i zapewne bolesne jest nie tylko milczenie ukochanej bliskiej osoby (przecież mówiąc do kogoś pragniemy, by ta osoba nam odpowiedziała), ale również jego nieobecność. Zmarły co prawda pojawia się, jednak już po chwili znika, czego językowym wykładnikiem jest sformułowanie: „i znów i znów”, które zdaje się otwierać na nieskończoną liczbę takich powtórzeń. Zresztą cały fragment „Znikasz

i jesteś i znów i znów / między światłem i cieniem między przerwami drzew" może oznaczać krótkotrwałość pobytów zmarłego czy to we śnie, czy w pamięci, tak jak chwilowe są przerwy światła między rosnącymi przy drodze drzewami, rzucającymi na asfalt swoje długie cienie. W tym przypadku światło i cienie między przerwami drzew stają się metaforą cyklicznego pojawiania się i znikania.

Jednak wydaje się, że drzewa można także zinterpretować dosłownie i wyobrazić sobie, że zmarły przychodzi w śniącej się scenerii parku, wychylając na moment zza drzew, za którymi po chwili znika. Być może osoba śniąca próbuje go nawet dogonić, stąd jej wezwanie ,stań”, umieszczone w tytule wiersza oraz powtórzone w tekście „stań zatrzymaj się”. Czytelnik, idąc tym tropem, światło i cień zinterpretuje jako przestrzeń życia i przestrzeń śmierci. Zwłaszcza że poetka mówi „W cieniu nie jesteś sobą chcę cię znów w jasności”, czyli żywego, nie umarłego, a więc innego choćby $\mathrm{w}$ tym sensie, że pozbawionego ciała ${ }^{5}$. Wszakże posiadanie ciała uniemożliwiałoby ukochanemu tak szybkie znikanie. Jak czytamy: „nie ma we mnie zgody na twoją zdolność odchodzenia”.

Osobną kwestią, którą czytelnik powinien rozważyć jest zastosowanie w wierszu czasu teraźniejszego, który chwilę obecną wydaje się rozciągać w

${ }^{4}$ Tak samo w wierszu Którejś nocy [9], zmarły nie odpowiada na słowa poetki, choć pojawia się informacja, że którejś nocy zawołał jej imię. Co ciekawe, między wierszem Którejś nocy a utworem Przechodzień można dostrzec analogię, która polega na tym, że zmarli chodzą ulicami, co może symbolizować wygnanie z życia, ale jednocześnie niemożliwość całkowitego odejścia ze świata.

${ }^{5}$ Bo dusza: „Ciałem myśli i czuje bywa poważna i żartobliwa / ciałem dotyka i kocha i patrzy / i szaleje i krzyczy i boli ją i nienawidzi / Jakże będzie to czynić pozbawiona ciała [...]” (Dusza), [9]. 
nieskończoność. „Teraz” trwające od chwili śmierci ukochanej bardzo bliskiej osoby staje się „teraz” wiecznym. Śmierć stanowi zatem wyrwę w czasie, pogrążenie w bólu tak trwałe, że cały świat zdaje się zatrzymywać w miejscu.

Jakie emocje wypełniają omawiany wiersz? Zdaniem Małgorzaty Czermińskiej, jest to rozpacz, która zastąpiła częstą w elegijnych utworach Hartwig melancholię [2, s. 209]. Przy czym - co trzeba podkreślić - ta rozpacz nie wyraża się krzykiem. Wyraźne jest tu dążenie poetki do stoickiego zdystansowania się wobec doświadczanego cierpienia, które przejawia się w wyważonym języku wypowiedzi, choć wyrażone w potocznym sformułowaniu żądanie ,chcę się znów w jasności” pozwala nam stwierdzić, że poetka $\mathrm{z}$ trudem radzi sobie $\mathrm{z}$ wszechogarniającym i niepokonanym bólem.

Jednak w końcówce wiersza pojawia się ton całkowicie odmienny. Poetka mówi: „mój bólu moja radości tak uchwytna nawet w pamiętaniu”. Zatem z bólem miesza się radość, wywołana przez stoickie pokonanie rozpaczy wciągającej człowieka w duchową przepaść. To radość z odwzajemnionej szczęśliwej miłości i poczucie obdarowania przez los [2, s. 209; 10, s. 27], która właśnie dzięki pamięci umożliwia przeżycie „czasu gdy trzeba będzie płakać” (Śpiew, [w:] Zobaczone, 1999).

Pamięć jest właściwą tylko człowiekowi zdolnością ocalania przeszłości: „Ale wyławiamy chwile szczęśliwe - pisze poetka w wierszu To się dzieje (Nie ma odpowiedzi, 2001) - Wszak należy nam się jakaś nagroda / za zbrodnie jakich dokonuje na nas czas". W pamięci skrywają się prawdy, ale też lęki - często nieuświadomione, co najwyżej przeczuwane, które poetka próbuje wydobyć i wypowiedzieć, a w konsekwencji zmierzyć się w nimi (w czym uczestniczą także jej czytelnicy).

W utworach poświęconych przemijaniu człowieka, jego śmierci i związanemu z tym cierpieniu Julia Hartwig przez pryzmat konkretnego i bardzo realistycznie przedstawionego zdarzenia, ukazuje sprawy uniwersalne, wspólne wszystkim ludziom. Podobnie jest w utworach poświęconych śmierci członków własnej rodziny, a także poetów - współczesnych i dawnych. Elementy autobiograficzne zawsze zostają tu przetransponowane na ogólność, celem odsłonięcia i wypowiedzenia niewyrażalnych egzystencjalnych prawd, które dotyczą każdego z nas.

Podsumowanie. W poezji Julii Hartwig świat nie ogranicza się do jego dziennej, widzialnej sfery, lecz jest złożony $\mathrm{z}$ wielu równoprawnych odnóg, $\mathrm{z}$ nieoczywistych i niejawnych sfer rzeczywistości, w których skrywa się niewyrażalne. Można zatem powiedzieć, że niewyrażalne stanowi wewnętrzną strukturę widzialnego świata, ale dojście do niego jest możliwe jedynie poprzez świat widzialny i dotykalny. Cała więc rzeczywistość pełna jest tajemnych przesłań - mówi do nas przyroda, ale także odwiedzające nas we śnie oraz na jawie duchy i zjawy.

Podejmowane przez poetkę próby wyrażenia niewyrażalnego wiążą się $\mathrm{z}$ dążeniem do maksymalnej jasności i przejrzystości wypowiedzi. Słowo w poezji Hartwig nigdy nie jest celem samym w sobie, ale tylko środkiem artykulacji tego, 
co wypowiedzeniu się opiera. Poetka waży każde słowo, przeciwstawiając się tym samym poezji niechlujnej i niedopracowanej.

Wśród gatunków uprawianych przez Julię Hartwig najważniejszy jest poemat prozą, który poetka upodobała sobie najbardziej i który w największym chyba stopniu odpowiada jej widzeniu i rozumieniu otaczającego świata: „Chciałabym podkreślić, że poetycka proza jest formą, którą niejako sama w sobie odkryłam i mimo że na początku była dziełem przypadku, kształtowałam ją potem świadomie. Wiem, że jest to forma trudna, może dlatego, że bardzo pojemna i usytuować w niej można całą gamę niuansów, od tonacji żartobliwo-ironicznych do powagi, a nawet paradoksu. To są jej potencjalne możliwości, choć z pewnością sama nie wszystkie je wykorzystuję. Forma ta $\mathrm{z}$ zasady jest statyczna i trzeba nieco wyobraźni, aby wykrzesać z niej napięcie, dzianie się, przenikanie, cały ten ruch świadczący o jej żywotności” [13].

Obok poematów, poetka nierzadko komponuje wiersze wolne, których zasadniczą cechą, tak samo zresztą jak w poematach jest długa fraza i prosta języka. Nie oznacza to rezygnacji $\mathrm{z}$ zastosowania rozmaitych środków stylistycznych, z których najczęstsza wydaje się metafora, jednakże nigdy nie jest ona zbyt daleka i zbyt trudna do zrozumienia.

Wreszcie trzecim elementem poetyckiej twórczości Julii Hartwig są „błyski” małe utwory mieszczące się w estetyce fragmentu, będące zatrzymanymi w słowie epifaniami doświadczanej przez poetkę rzeczywistości. W „błyskach” można widzieć swoisty materiał do wiersza, jego zalążek, czy też pomysł na wiersz, ale co ważne - „błyski” są też formą umotywowaną przez niespójny, nieciągły i dynamiczny charakter nowoczesnego doświadczenia; a jednocześnie są zapisem tego doświadczenia, które nie daje się wyrazić pod postacią narracji ciągłych i linearnych [16;17]. W tym sensie można by mówić o nowym quasi-gatunku literackim, na co wskazała już Zofia Zarębianka, choć niestety jej opinia wciąż jest osamotniona: „W ostatnich latach wyodrębnia się jeszcze jedna linia poetyki Julii Hartwig, reprezentowana najpełniej przez tom Błyski. Tytuł wskazuje tu zarazem na próbę stworzenia nowego gatunku, krótkich tekstów »rozbłyskujących « zaskakującym sensem, tekstów będących niekiedy tylko drobnym fragmentem, jednym wersem rodzącej się myśli, skojarzenia, metafory. Często zresztą nie są to nawet własne teksty poetki, ale zacytowany urywek, zasłyszana rozmowa, prasowa notatka. Mimo niewątpliwej inności - w sferze poetyckiej formy - w stosunku do dotychczasowych dokonań poetki, »błyski« nie uchylają uwag dotyczących konstytutywnego dla poezji Julii Hartwig światoodczucia" [15, s. 54].

Julii Hartwig nierzadko przypisuje się opinię poetki racjonalnej. W czym ów racjonalizm miałby się przejawiać? Na pewno w przypisywanym jej często przez krytyków klasycyzmie, ale rozumianym jako klasyczna dyscyplina i umiar ${ }^{6}$, który ustala ład wewnątrz utworu, pilnując, by jakiś element materii poetyckiej nie przybrał przesadnych kształtów (notabene - jak podkreśla Stanisław Barańczak zwrot w stronę „trwałej symboliki”, powagi i pozbawionej ozdobników

${ }^{6}$ „Dla Julii Hartwig, jak dla prawdziwego klasyka, miarą jest właśnie umiar. Wzorem umiaru stała się, jak w mitach, fala morska" [12, s. 68]. 
bezpośredniości to zjawisko szersze, zaznaczające się w ostatnich latach $\mathrm{u}$ wielu poetów rozmaitych orientacji i pokoleń.). Z kolei nie ma w poezji Hartwig klasycyzmu w sensie klasycystycznej jasności, bo jednak zbyt wiele tu ciemności. Nie ma też klasycystycznego patosu i dostojności, ale głos ściszony, zainteresowanie konkretem, antynomiczne widzenie rzeczywistości i również poczucie humoru. Przede wszystkim zaś poszukiwanie harmonii - dźwięków, języka i wreszcie świata. Jak pisze Małgorzata Baranowska: „W całej swojej twórczości Julia Hartwig stara się znaleźć odpowiednią miarę. Należy do tych poetów, którzy przez wieki kontynuują poszukiwanie harmonii; nie tylko harmonii dźwięków, języka, ale i harmonii świata. Wydawałoby się, że takich poetów trudno znaleźć w świecie współczesnym. Ale mimo poczucia mieszkańców XX wieku, że harmonia jest we współczesności nie do odnalezienia, a za naruszoną uważana była już w starożytności, tacy poeci istnieją" [1].

Racjonalizm Julii Hartwig przejawia się też w wierze w możliwości człowieka, w rozumne, poznające „Ja”, jednak jest to „Ja” w wersji ,ulepszonej”, tzn. „Ja” pogodzone w własną niewiedzą i nie roszczące sobie pretensji do jedynej prawdy ${ }^{8}$, ale zawsze wątpiące i niepewne, co wyraża się w odsuwaniu na dalszy plan subiektywnego horyzontu rozumienia świata i „oddania głosu” otaczającej rzeczywistości. Można powiedzieć, że Julia Hartwig nie tylko zaklina istnienie, żeby przetrwało, przeciwstawiając się dynamice rzeczywistości będącej odwiecznie płynącą heraklitejską rzeką, ale też dotyka niewidzialnego, czyniąc je widzialnym i dostępnym dla tych, którym nie jest dana zdolność poetyckiego widzenia. Porządkuje niestabilny świat przedmiotów i wyjaśnia niezrozumiały bieg rzeczy; zaś to, o czym mówi, co ukazuje, czyni niejako nieśmiertelnym, umieszczając $\mathrm{w}$ poezji to, co przemijające, obdarza je możliwością, ponownego zaistnienia i ożycia. Dlatego ma rację Ryszard Przybylski, pisząc: „[...] Julia Hartwig szukała rytmu w snach, które wznoszą poetę ponad sezonową wiedzę, jednego czy dwóch pokoleń i zanurzają go w bogactwie życia cenniejszym niż szum potocznego banału" $[12,80]$.

Odpowiadając zatem na pytania postawione przez poetkę $\mathrm{w}$ jednym $\mathrm{z}$ „błysków”: „Kto staje między mną a słowem. Kto staje między życiem a formułą. Między wydarzeniem a opowieścią o wydarzeniu. Między wzruszeniem a skamieliną. Między zielenią a słowem zieleń", powiemy: tajemnica, nienazwane, niewyrażalne.

\section{LITERATURA}

1. Baranowska M., Julia Hartwig - podróż do współczesności:

http://www.culture.pl/pl/culture/artykuly/es_hartwig_podroz_do_wspolczesnos ci.

2. Czermińska M., Żyjąc zyskujemy życie. O późnych wierszach Julii Hartwig, [w:] Księga Janion, oprac. Z. Majchrowski i S. Rosiek, Gdańsk 2007.

\footnotetext{
${ }^{7}$ Pisze o tym Piotr Śliwiński: „stawanie »po stronie istnienia«, wyraźne w wielu wierszach, [...] nie wydaje się witalistycznym odruchem czy prostą pochodną rozbudzonych zmysłów, ale wynika z szacunku dla rozumu i dyktowanej przezeń pokory. Poetka, mówiąc bowiem światu »tak«, często dopowiada »nie wiem«" [14, s. 96].

${ }^{8},[\ldots]$ podmiotem tych wierszy nie jest ego, wypełnione dumą z powodu jasnej samoświadomości. To jest $» j a \ll$ otwarte, o niejasnych granicach, otwarte na otaczający świat widzialny i niewidzialny. To ktoś pogodzony z własną niewiedzą, a jednak czerpiący z niej godność, a nawet pewien rodzaj dumy” [11, s. 63].
} 
3. Hartwig J., Chwila postoju, Kraków 1980.

4. Hartwig J., Jasne niejasne, Kraków 2009.

5. Hartwig. J., Kilka niechętnych uwag o pisaniu, „Topos” 1997, $\mathrm{nr} 4$.

6. Hartwig J., Nie ma odpowiedzi, Warszawa 2001.

7. Hartwig J., Obcowanie, Warszawa 1987.

8. Hartwig J., Stowo od Autorki, [w:] tejże, Wybór wierszy, Warszawa 2000.

9. Hartwig J., Zobaczone, Kraków 1999.

10. Legeżyńska A., Gest pożegnania, Poznań 1999.

11. Nasiłowska A., Poezja jako sposób poznania, „Odra” 1996, nr 5.

12. Przybylski R., To jest klasycyzm, wstęp M. Janion, Warszawa 1978.

13. Sztuka widzenia (wywiad Grażyny Drabik z Julią Hartwig na łamach „Przeglądu

http://www.dziennik.com/www/dziennik/kult/archiwum/07-12-02/pp-10-1101.html.

14. Śliwiński P., Przygody w wolnościa. Uwagi o poezji wspótczesnej, Kraków 2002.

15. Zarębianka Z., Czas przeszły - na chwile nieutracony. O poezji Julii Hartwig, „Topos” 2004, nr 3-4 (76-77).

16. Żmudzka-Brodnicka M., „Błyski” Julii Hartwig - rozważania genologiczne, „Kijowskie Studia Polonistyczne”, Kijów 2011, t. XVIII.

17. Żmudzka-Brodnicka M., Czym sa „,blyski” Julii Hartwig? [w:] Wokót problemów $z$ interpretacja $i$ historia, pod red. E. Nawrockiej, M. ŻmudzkiejBrodnickiej, W. Płotki i J. Żerki, Gdańsk 2011.

У статті зосереджено увагу на вибраних творах Юлії Гартвіг, у яких поетка намагається вербалізувати (безсумнівно, це успішна спроба) одне із неминучих $i$ найбільш загадкових правил людського існування, а саме необхідність померти. Досвід швидкоплинності $i$ навіть постійну присутність смерті поетка висловлює внаслідок пильного спостереження за видимою реальністю, очевидною і навіть банальною, яку щьоразу долає, щоб вхопити те, щчо таємниче і невимовне. Поезія Юлії Гартвіг сповнена слідів відвідування мертвими світу живих, водночас наяву й уві сні, щзо є доказом того, що ці два світи - живих і мертвих - перетинаються; більше того, щчо світ мертвих $і$ живих є неділимою єдністю. Це переплетення для поетки $\epsilon$ звичайним, тому прояви смерті в житті або світу мертвих у світі живих вона описує абсолютно рачіонально.

Ключові слова: Юлія Гартвіт, смерть, швидкоплинність, рачіоналізм.

The article is devoted to the selected song by Julia Hartwig, in which the poet is trying to put into words - and no doubt it is a successful attempt - one of the most inevitable and mysterious regulations of human existence, namely the necessity of dying. Experience passing, and even the constant presence of death expresses the poet through careful observation of the visible reality, obvious and even banal, but each time he does, to capture what mysterious and inexpressible. The poetry of Julia Hartwig is no shortage of visits to the dead in the world of the 
Синопсис: текст, контекст, медіа, № 3 (11), 2015

living, both awake and asleep, which is proof that these two worlds - the living and the dead intermingle, and maybe even more, that the world of the dead and the living are an integral unity. This weave is usual for the poet's, because these manifestations of death in life, or the world of the dead in the world of the living describes in a completely rational.

Keywords: Julia Hartwig, death, transience, rationalism. 